Жуковська О.А.

канд. фіз.-мат. наук, дочент ORCID ID: 0000-0003-1110-9696

Хома М.M.

ORCID ID: 0000-0002-3232-6537

Національний технічний університет Украӥни «Київський політехнічний інститут імені Ігоря Сікорського»

\title{
ЕКОНОМІКО-МАТЕМАТИЧНЕ МОДЕЛЮВАННЯ РОЗВИТКУ ПІДПРИСМСТВА У СФЕРІ ТУРИЗМУ
}

\section{ECONOMIC AND MATHEMATICAL MODELING OF BUSINESS DEVELOPMENT IN THE FIELD OF TOURISM}

У статті побудована математична модель аналізу $i$ прогнозування діяльності туристичного підприємства з урахуванням зовнішніх інвестицій. Побудовано математичну залежність динаміки приросту кількості туристів від різних видів інвестицій, оскільки інвестування є однією з опор, на яких будується фундамент ринкової економіки, а інвестищії, зокрема іноземні, є надважливими для розвитку економіки нашої краӥни.

Туристична сфера є однією із стратегічних галузей економіки, за допомогою якої відбувається подальший сочіально-економічний розвиток держави, а для формування туристичного ринку та успішного розвитку начіонального туризму необхідним є не лише наявність ряду складових туристичної індустрії і туристично-рекреаційний потенціал, а й наявність сприятливого інвестииійного клімату та механізму надходження інвестицій у туристичну галузь. Вирішення изієї проблеми дасть змогу підвищити зростання соиіальноекономічних показників підприємств, регіону та країни загалом. Тому необхідно розробити модель, яка б враховувала вплив иих факторів для створення максимально ефективного плану розвитку туристичного підприємства.

Показано, щзо запропонована модель дозволяє дослідити динаміку розвитку та проаналізувати різні стратегії поведінки туристичного підприємства на ринку. Розглянуто такі можливі види інвестицій, основною метою яких є збільшення кількості туристів, прибутку, зменшення плати за інвестищіі та збільшення коефіцієнту реінвестування. Для розглядуваних стратегій проведено порівняння динаміки основних показників: прибутку та плати за інвестиції. В результаті визначений ефективний вид інвестииій, який дозволить збільшити потік туристів, $і$ як наслідок зберегти та посилити конкурентну позищію підприємства на ринку.

Отже, необхідність організації інвестування в туристичній сфері обумовлює велику практичну потребу в проведенні досліджень інвестиційного прочесу в туристичному бізнесі $i$ теоретичному обтрунтуванні вибору напрямків активізації інвестиційної діяльності, $i$ саме запропонована модель дозволяе визначити напрям інвестиційної політики туристичного підприємства, оперуючи основними показниками його діяльності.

Ключові слова: туристичне підприємство, моделювання, інвестиції, динаміка розвитку.

In the article the mathematical model of the analysis and forecasting of the activity of the tourist enterprise taking into account foreign investments is constructed. The mathematical dependence of the dynamics of the growth of the number of tourists on different types of 
investments has been constructed, since investing is one of the pillars on which the foundation of a market economy is being built, and investments, in particular foreign ones, are extremely important for the development of our country's economy.

The tourism sector is one of the strategic sectors of the economy, with the help of which further socio-economic development of the state is taking place. For the formation of the tourism market and the successful development of national tourism, it is necessary not only the presence of a number of components of the tourism industry and tourist and recreational potential, but also the presence of a favourable investment the climate and the mechanism of investment in the tourism industry. Solving this problem will allow to increase the growth of socio-economic indicators of enterprises, the region and the country as a whole. Therefore, it is necessary to develop a model that takes into account the influence of these factors on creating the most effective plan for the development of a tourism enterprise.

It is shown that the proposed model allows to study the dynamics of development and analyse various strategies of the behaviour of a tourist enterprise in the market. The following possible types of investments are considered, the main purpose of which is to increase the number of tourists, profit, reduce the payment for investment and increase the reinvestment factor. For the considered strategies, a comparison of the dynamics of the main indicators: profit and payment for investment. As a result, an effective type of investment is identified that will increase the flow of tourists, and as a consequence, preserve and strengthen the competitive position of enterprises in the market.

Consequently, the necessity of investing in the tourism sector necessitates a large practical need for conducting research on the investment process in the tourism business and the theoretical justification for choosing the areas for intensifying investment activity, and the proposed model allows determining the direction of investment policy of the tourist enterprise, operating on the main indicators of its activities.

Keywords: tourism enterprise, modelling, investments, development dynamics.

Вступ. В даний час в Україні активно формується нове ставлення до розвитку туризму як однієї з провідних галузей економіки. Незважаючи на досить високий потенціал доля туризму в ВВП України становить менше 2\%, тимчасом як в інших країнах цей показник може досягати 50\%. Така ситуація склалася внаслідок багатьох причин, одна 3 яких - нестача коштів як для розбудови існуючих великих туристичних комплексів, так і для створення нових. Підвищення стандартів сервісу, створення більш комфортних умов, розвиток інфраструктури біля туристичних комплексів, реклама історичних пам'яток та цікавих місць - все це потребує певних фінансових вкладень. Також ключовим питанням розвитку туризму $\epsilon$ не тільки правильна інвестиційна політика, а й професійне використання отриманих коштів 3 метою отримання прибутку. Необхідність організації інвестування в туристичній сфері обумовлює велику практичну потребу в проведенні досліджень інвестиційного процесу в туристичному бізнесі України і теоретичному обгрунтуванні вибору напрямків активізації інвестиційної діяльності [7-13]. Невирішеними залишаються розробка практично реалізованих моделей $\mathrm{i}$ обгрунтування пропозицій щодо формування i розвитку систем управління туристичним бізнесом, i підвищенню конкурентоспроможності якості товарів i послуг, пропонованих на туристичному ринку України, на основі системного підходу [14-16]. Саме тому розробка нових підходів до моделювання об'єктів сфери туристичних 
послуг, створення нових методів і моделей, $є$ важливою i актуальною науковою проблемою, яка потребує невідкладного вирішення.

Постановка завдання. Метою даної статті $\epsilon$ дослідження та аналіз поточного стану і економічного розвитку туристичного підприємства за рахунок ефективної інвестиційної діяльності.

Методологія. Основою дослідження є праці вітчизняних і зарубіжних вчених 3 теорії підприємництва, розвитку малого підприємництва [1-6], економіко-математичного моделювання підприємств у сфері туризму [13-14]. В якості основного інструментарію використані методи розв'язання диференціальних рівнянь, зокрема, лінійних неоднорідних рівнянь 3 постійними коефіціснтами.

Результати дослідження. Розвиток туристичного підприємства залежить як від внутрішніх джерел (прибутку), так і зовнішньої фінансової підтримки у вигляді інвестицій. Для вибору найбільш ефективної інвестиційної стратегії було проведено аналіз впливу різних видів інвестицій на розвиток туристичного підприємства та визначено, яка інвестиційна стратегія $€$ найефективнішою.

Вважатимемо, що основні фонди є єдиним фактором, який визначає можливість прийняти певну кількість туристів. Туристичне підприємство функціонує при незмінній технології, що передбачає сталість його фондовіддачі. Таким чином, з урахуванням зроблених передумов, виробнича діяльність описується однофакторною виробничою функцією типу Леонтьєва, а темпи розвитку підприємства визначаються динамікою основних фондів:

$$
P(t)=f A(t)
$$

де

$P(t)$ - потік туристів в момент часу $t$ у вартісному вираженні, $f$ - показник фондовіддачі, $A(t)$ - вартість основних фондів.

Процес формування прибутку за відрахуванням витрат на утримання туристів:

$$
\Pi(t)=(1-c) P(t)
$$

де $c$ - частка витрат на утримання туристів і реалізацію послуг по відношенню до прибутку.

Величина чистого прибутку за відрахуванням податків:

$$
\Pi_{0}(t)=\Pi(t)-W(t)
$$

де $W(t)$ - сума податкових відрахувань

Алгоритм нарахування податкових відрахувань, що складаються із податку на прибуток на податку на додану вартість. При цьому пільги, що 
надаються підприємствам, які реінвестують свій прибуток у виробництво, враховуються за допомогою частки інвестиційних відрахувань $\xi$ і коефіцієнта $k$ :

$$
W(t)=\tau_{1} P(t)+\tau_{2} k(1-\xi) \Pi_{0}(t),
$$

де

$\tau_{1}, \tau_{2}-$ ставки оподаткування на додану вартість та податок на прибуток відповідно,

$\xi$ - частка чистого прибутку, відрахованого на реінвестування,

$k$ - коефіцієнт, який відображає частку реінвестованих засобів прибутку, які не мають пільг на оподаткування,

Динаміка приросту основних фондів за рахунок власних джерел та зовнішніх інвестицій:

$$
\begin{aligned}
& \frac{d A(t)}{d t}=\xi \Pi_{0}(t)+I(t), \\
& t \in[0, \mathrm{~T}], \quad \xi \in[0,1], k \in[0,1],
\end{aligned}
$$

де $I(t)$ - обсяги зовнішніх інвестицій.

Для того, щоб виразити чистий прибуток, підставимо рівняння (2) і (4) в (3):

$$
\Pi_{0}(t)=(1-c) P(t)-\tau_{1} P(t)-\tau_{2} k(1-\xi) \Pi_{0}(t),
$$

Із (6) виразимо змінну $\Pi_{0}(t)$ :

$$
\Pi_{0}(t)=\frac{\left(1-c-\tau_{1}\right) f A(t)}{1+\tau_{2} k(1-\xi)} .
$$

Підставляючи в (5) отримаємо:

$$
\frac{d A(t)}{d t}=\xi\left[\frac{\left(1-c-\tau_{1}\right) f A(t)}{1+\tau_{2} k(1-\xi)}\right]+I(t) .
$$

Нехай

$$
a=\xi\left[\frac{\left(1-c-\tau_{1}\right) f}{1+\tau_{2} k(1-\xi)}\right]
$$

Тоді отримаємо таке диференційне рівняння:

$$
\frac{d A(t)}{d t}=a A(t)+I(t)
$$


Сприятливі умови розвитку забезпечуються, якщо

$$
\frac{d A(t)}{d t}>0
$$

Розглянемо три випадки динаміки інвестицій:

- постійні інвестиції з фіксованими об'ємами для кожного періоду

$$
I(t)=I_{0}=\text { const },
$$

- інвестиції, що зростають по лінійному закону 3 темпом росту інвестицій $\beta>0$

$$
I(t)=\beta t,
$$

- інвестиції, що зростають по нелінійному (експоненціальному) закону iз середнім темпом росту інвестицій $\beta>0$ та мінімальним рівнем інвестицій при $I(0)=B$

$$
I(t)=B e^{\beta t},
$$

Розглянемо розв'язок моделі

$$
\frac{d A(t)}{d t}=a A(t)+I(t)
$$

де $I(t)$ - постійні інвестиції з фіксованими об’ємами для кожного періоду:

та

$$
I(t)=I_{0}=\text { const }
$$

$$
a=\xi\left[\frac{\left(1-c-\tau_{1}\right) f}{1+\tau_{2} k(1-\xi)}\right] .
$$

Загальне рішення лінійного неоднорідного диференціального рівняння має вигляд:

$$
A(t)=\left(A_{0}+\frac{I_{0}}{a}\right) e^{a t}-\frac{I_{0}}{a} .
$$

Далі розглянемо розв'язок моделі, коли інвестиції зростають по лінійному закону з темпом росту інвестицій $\beta>0$ :

$$
I(t)=\beta t
$$

Загальне рішення лінійного неоднорідного диференціального рівняння має вигляд:

$$
A(t)=A_{0}(t) e^{a t}-\frac{\beta}{a^{2}}\left(e^{a t}+a t+1\right) .
$$


Тепер розглянемо розв'язок моделі, де інвестиції зростають по нелінійному (експоненціальному) закону із середнім темпом росту інвестицій $\beta>0$ та мінімальним рівнем інвестицій при $I(0)=B$ :

$$
I(t)=B e^{\beta t} .
$$

Загальний розв'язок лінійного неоднорідного диференціального рівняння має вигляд:

$$
A(t)=\left(A_{0}-\frac{B}{\beta-a}\right) e^{a t}+\frac{B}{\beta-a} e^{\beta t} .
$$

На рис. 1 представлені результати тимчасової динаміки основних фондів туристичного підприємства при постійних інвестиціях для значення питомої собівартості с $=0,6$.

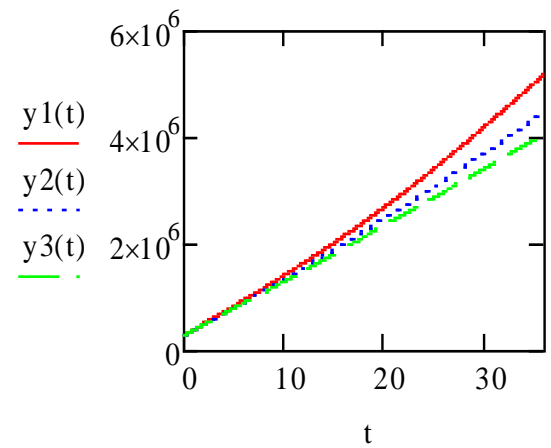

Рисунок 1 - Залежність вартості основних фондів туристичного підприємства: суцільна лінія $\xi=0,6$; точкова лінія $\xi=0,3$; пунктирна лінія $\xi=0,1$

3 рис. 1 видно, що плив параметра реінвестування $\xi$ на величину основних фондів є вельми істотним.

На рис. 2 представлені результати тимчасової динаміки фондів туристичного підприємства для значення питомої собівартості с $=0,6$ при інвестиціях, які зростають по лінійному закону.

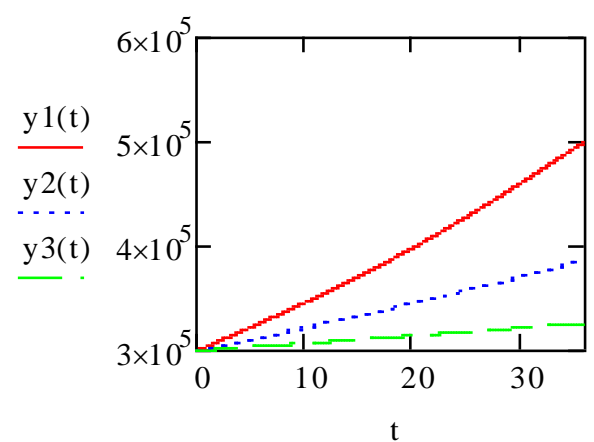

Рисунок 2 - Залежність вартості основних фондів туристичного підприємства від t при інвестиціях, які зростають по лінійному закону: суцільна лінія $\xi=$ 0,6 ; точкова лінія $\xi=0,3$; пунктирна лінія $\xi=0,1$ 
На рис. 3 представлені результати тимчасової динаміки основних фондів туристичного підприємства для значення питомої собівартості с $=0,6$ при інвестиціях, які зростають по нелінійному (експоненціальному) закону.

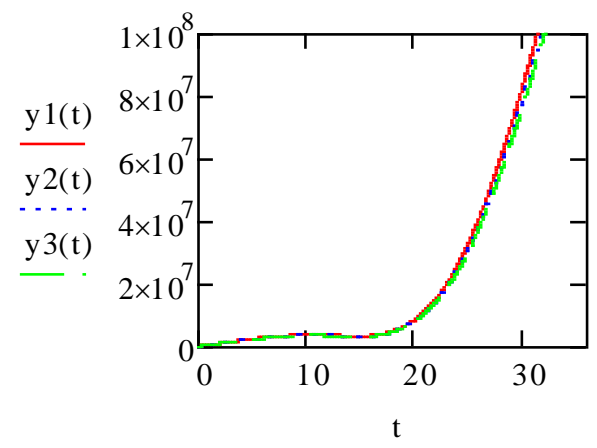

Рисунок 3 - Залежність вартості основних фондів туристичного підприємства від t при інвестиціях, які зростають по нелінійному (експоненціальному) закону: суцільна лінія $\xi=0,6$; точкова лінія $\xi=0,3$; пунктирна лінія $\xi=0,1$

Розглянемо 3 види інвестицій, який від них буде прибуток та скільки підприємству доведеться повернути інвестору (за постійні інвестиції - 3\% кожного періоду, за інвестиції, які зростають по лінійному закону $-5 \%$, за інвестиції, які зростають по експоненціальному закону - 7\%).

У таблиці 1 наведено суму прибутку туристичного підприємства (тис. грн.) та плата за інвестиції (тис. грн.) при постійних інвестиціях за 12, 24 та 36 місяця.

Таблиця 1- Прибуток туристичного підприємства при постійних інвестиціях

\begin{tabular}{|c|c|c|}
\hline $\begin{array}{c}\text { Період, } \\
\text { місяці }\end{array}$ & $\begin{array}{c}\text { Прибуток, тис. } \\
\text { грн }\end{array}$ & $\begin{array}{c}\text { Плата за } \\
\text { інвестиції, } \\
\text { тис.грн }\end{array}$ \\
\hline 12 & $8.451 \cdot 10^{3}$ & 253,54 \\
\hline 24 & $1.003 \cdot 10^{4}$ & 300,834 \\
\hline 36 & $1.19 \cdot 10^{4}$ & 356,962 \\
\hline
\end{tabular}

У таблиці 2 наведено суму прибутку туристичного підприємства (тис. грн.) за 12, 24 та 36 місяці та плата за інвестиції (тис. грн.), які змінюються за лінійним законом.

Таблиця 2 - Прибуток туристичного підприємства при інвестиціях, які змінюються за лінійним законом

\begin{tabular}{|c|c|c|}
\hline $\begin{array}{c}\text { Період, } \\
\text { місяці }\end{array}$ & $\begin{array}{c}\text { Прибуток, тис. } \\
\text { грн }\end{array}$ & $\begin{array}{c}\text { Плата за } \\
\text { інвестиції, } \\
\text { тис. грн }\end{array}$ \\
\hline 12 & $8,451 \cdot 10^{3}$ & 422,567 \\
\hline 24 & $1,003 \cdot 10^{4}$ & 501,39 \\
\hline 36 & $1,19 \cdot 10^{4}$ & 594,937 \\
\hline
\end{tabular}


У таблиці 3 наведено суму прибутку туристичного підприємства (тис. грн.) за 12, 24 та 36 місяці та плата за інвестиції (тис. грн.), які змінюються за експоненціальним законом.

Таблиця 3- Прибуток туристичного підприємства при інвестиціях, які змінюються за експоненціальним законом

\begin{tabular}{|c|c|c|}
\hline $\begin{array}{c}\text { Період, } \\
\text { місяці }\end{array}$ & $\begin{array}{c}\text { Прибуток, тис. } \\
\text { грн }\end{array}$ & $\begin{array}{c}\text { Плата за } \\
\text { інвестиції, } \\
\text { тис. грн }\end{array}$ \\
\hline 12 & $9,351 \cdot 10^{4}$ & $6,546 \cdot 10^{3}$ \\
\hline 24 & $6,255 \cdot 10^{5}$ & $4,379 \cdot 10^{4}$ \\
\hline 36 & $3,855 \cdot 10^{6}$ & $2,699 \cdot 10^{5}$ \\
\hline
\end{tabular}

Висновки. Для розвитку туристичного сектора в Україні необхідно збільшувати та удосконалювати існуючу виробничу базу, що може бути здійснене шляхом припливу довгострокових інвестицій i створення ефективного механізму їх залучення і використання як на рівні держави, так i серед суб'єктів туристичного бізнесу. Саме тому була створена модель розвитку туристичного підприємства та розглянуто залучення інвестицій при різних умовах. В ході дослідження було визначено, що найбільш вигідно для туристичного підприємства залучати постійні інвестиції, оскільки завдяки ним туристичне підприємство отримує більший прибуток, ніж при інвестиціях, які зростають по лінійному закону, і відсоток плати за них значно менший, ніж за інвестиції, що зростають експоненційно. Також це дасть можливість збільшити частку прибутку, яка відраховується на реінвестування. Оскільки раніше було визначено, що вплив параметра реінвестування на величину основних виробничих фондів $є$ вельми істотним, то залучення саме постійних інвестицій $є$ найбільш вигідним для розвитку туристичного підприємства.

\section{Література:}

1. Жуковська О.А., Ковальова В.В. Формальна модель прийняття кредитного рішення малим підприємством/ Економіка: проблеми теорії та практики.- Збірник наукових праць - Д.: ДНУ, 2010. - Вип.260 - Т. II. - С.421-427.

2. Жуковська О.А., Нікітіна П.А.Економіко-математичне моделювання ємності ринку та ринкової частки компанії/Журнал “Економічний вісник”.- 2016. - № 13 - С.546-550.

3. Жуковська О.А., Нікітіна П.А.Економіко-математичне моделювання ринкової діяльності компанії/Журнал “Економічний вісник”.- 2017. - № 14 - С.471-475

4. Егорова Н.Е. Применение дифференциальных уравнений для анализа динамики развития малих предприятий, использующих кредитно-инвестиционный ресурс / Н.Е. Егорова, С.Р. Хачатрян // Экономика и математические методы. - 2006. - № 1. C.50-67.

5. Шерстенников Ю.В. Модель влияния темпов внедрения инновационных решений на динамику развития малого предприятия / Ю.В. Шерстенников, Л.В. Ромащук // Економіка: проблеми теорії та практики: Збірник наукових праць. - Випуск 222: в 5 т. Т. III. - Дніпропетровськ: ДНУ, 2007. - С.468-480. 
6. Протасов Д.Н. Развитие модели кредитно-инвестиционных ресурсов промышленного предприятия - М. : Наука, 1985. - С.225

7. Ворошилова Г. О. Розвиток інвестиційних процесів у міжнародному туризмі / Г. О. Ворошилова // Проблеми розвитку зовнішньоекономічних зв'язків і залучення іноземних інвестицій: регіональний аспект. - Донецк : ДонНУ, 2010. - С.1050

8. Дядечко Л. п. Економіка туристичного бізнесу / Л. П. Дядечко. - К. : Центр навч. літри, 2007. - С.224

9. Кальченко О. М. Теоретичні аспекти інноваційної діяльності підприємств туристичної галузі / О. М. Кальченко // Вісник Чернігівського державного технологічного університету. Серія : Економічні науки. - Чернігів : ЧНТУ, 2011. - № 54 - С.147-155.

10. Любіцева О. О. Туристичні ресурси України / О. О. Любіцева, Є. В. Панкова, В. І. Стафійчук. - К. : Альтерпрес, 2007. - С.369.

11. Мальська М. п. Міжнародний туризм і сфера послуг / М. П. Мальська, Н. В. Антонюк, Н. М. Ганич. - К. : Знання, 2008. - С.661.

12. Свида I. В. Сучасний стан, актуальні проблеми та перспективи розвитку вітчизняного ринку туристичних послуг / I. В. Свида // Науковий вісник Ужгородського університету. - 2009. - № 28(3). - С.64 - 69.

13. Семенова Ю. А. Практическое использование адаптивных моделей в туризме / Ю. А. Семенова, А. А. Демин // Культура народов Причерноморья. - Симферополь: Межвузовский центр «Крым», 2001. - № 16. - С.34 - 39.

14. Ткаченко т. І. Сталий розвиток туризму: теорія, методологія, реалії бізнесу: монографія / Т. І. Ткаченко. - К. : Київ. нац. торг.-екон. ун-т, 2006. - С.537.

15. Трамова А. М. Математическое моделирование развития туризма в сфере услуг: [Электронный ресурс] / А. М. Трамова // Сетевой электронный научный журнал «Системотехника». - 2010. - № 8. - Режим доступа: http:// systech.miem.edu.ru/2010/tramova.htm

16. Шупік Б. В. Зарубіжний досвід у регулюванні туризму / Б. В. Шупік // Держава та регіони. - 2009. - № 1. - С.200 - 207. 